\title{
CARDINAL STEFAN WYSZYŃSKI'S PERSONALIST-COMMUNITARIAN CONCEPT OF THE STATE AND THE SOCIO-POLITICAL TRANSFORMATIONS OF POLAND IN THE POST-WAR DECADES
}

\begin{abstract}
The article debates the issues of the personalist-communitarian concept of social life presented by Cardinal Stefan Wyszyński in the context of the political and social transformations taking place in Poland in the post-war decades. In his praxeological approach, Wyszyński perceives the breakdown of the Christian community and morality as the primary social problem caused by the destructive influence of a human being inscribed in the ideology of collectivism and individualism. Therefore, the above article analyzes the specifics of "incomplete" concepts of man, as well as criticizes the doctrines responsible for the adverse effects of the socio-political changes taking place in the post-war decades of Polish history. This paper also proposes ways in which contemporary models of social life can shape the socio-political reality based on a genuinely humanistic vision of man and citizen.
\end{abstract}

Keywords: state, Cardinal Stefan Wyszyński, personalism, communitarianism, "socialist democracy", political transformation, common good

1 Fr. dr Ryszard Ficek, STD, PhD, priest of the diocese of Rockville Center/NY, the moral theologian and political scientist, a former lecturer of the Jordan University College in Morogoro/Tanzania, specializing in the moral theology, church history and international relations; ORCID: 0000-0001-5238-6767. Address for correspondence: 3300 Depot Ln, Cutchogue, NY 11935 USA, e-mail: rficek@optonline.net. 


\section{PERSONALISTYCZNO-WSPÓLNOTOWA KONCEPCJA PAŃSTWA WEDŁUG KARDYNAŁA STEFANA WYSZYŃSKIEGO A PRZEMIANY SPOŁECZNO-USTROJOWE W POLSCE W DEKADACH POWOJENNYCH}

\section{Streszczenie}

Prezentowany artykuł omawia kwestię personalistyczno-wspólnotowej koncepcji życia społecznego przedstawionej przez kardynała Stefana Wyszyńskiego w kontekście przemian ustrojowo-społecznych zachodzących w Polsce w okresie powojennym. Wyszyński postrzega rozpad wspólnoty i moralności chrześcijańskiej jako główny problem społeczny spowodowany przez destruktywny wpływ błędnych koncepcji człowieka wpisanych w ideologię kolektywizmu i indywidualizmu. Prezentowany artykuł analizuje specyfikę „niepełnych” koncepcji osoby ludzkiej w kontekście chrześcijańskiej wizji człowieka, jak również dokonuje krytyki ideologii odpowiedzialnych za negatywne skutki przemian społeczno-politycznych zachodzących w powojennych dekadach historii Polski. Niniejsza analiza proponuje również sposoby, dzięki którym współczesne modele życia publicznego mogą kształtować rzeczywistość społeczno-polityczną na „miarę osoby ludzkiej”, w oparciu o autentycznie humanistyczną wizję człowieka i obywatela.

Słowa kluczowe: państwo, kardynał Stefan Wyszyński, personalizm, komunitaryzm, „demokracja socjalistyczna”, transformacja polityczna, dobro wspólne

\section{Introduction}

The political dimension of Christian social life in the teaching of Primate Wyszyński especially in the post-conciliar period - is included in the work of evangelization, which is part of the universal mission of the Church. Service for the common good, performed in a prudent, morally correct way, with love and courage is an essential component to a Christian's political commitment.

The Christian understanding of politics, therefore, has nothing to do with moral relativism or class struggle - as understood by Marxist ideology - but is an element of the testimony of faith and is one of the forms of the Christian vocation, subordinated to the saving mission of the Church. A critical look at the model of socio-political life based on Marxist ideology, which was in force at that time, was aimed not only at pointing out the errors existing in a given system of social life but also at showing the fundamental norms and principles on which social life should be based. The active participation of Christians in political life - as an important dimension of social involvement - is, therefore, part of the essential dimension of the Church's mission, which is to care for the good of man. The difficult period of domination of Marxist ideology is a particular challenge for Christians, the implementation of which becomes a patriotic duty, an expression of the attitude of 
love for the motherland and attachment to the most critical values constituting national identity.

Various types of threats - caused by geopolitical conditions; the destructive influence of the system based on Marxist ideology; and the progressive moral degradation of society - call for constructive actions aimed at healing those threats that degenerate the sociomoral life of Poles. Opposition to pathological manifestations of social life is aimed at the nation's moral renewal - conditioning the positive character of all changes in Poland.

The period of total ideological indoctrination based on the monistic system of atheistic materialism led to enormous losses, both personal and material. The domination of the Marxist ideology in the Bolshevik version and the Polish intelligentsia's extermination during and immediately after the Second World War caused irreparable damage. It spiritually broke a large group of representatives of science and art. The consequence of this was a significant disruption of the fundamental structures of the nation's life and Polish culture, where the most critical threats were lack of ideology; weakening of the ethos; primitivism; vulgarity of some mass media; destruction of authorities; cosmopolitanism; the disappearance of patriotism; weakening of family ties; irreligion; hedonism; as well as moral permissiveness.

The awareness of co-responsibility for the full dimension of social life means that Christian political activity is not limited only to declarative acceptance of the truths it proclaims but has its practical aspect. Showing the basic principles of social life makes it possible to discover and overcome existing errors. Thus, the essential dimension of the political commitment of Christians, which determines the effectiveness of their activities, is the creation of structures of social and political life based on the authentic and fundamental values of love and justice, which need to be completed in truth and freedom. Only such a shaped social reality can lead to the desired peace, resulting from the personalist-communitarian social order.

In the context of the intensified atheization and secularization of the Polish society, Primate Wyszyński insists on the fundamental question: "Is it not better to mobilize all humanistic, moral, social, national, religious and Christian efforts in order to revive the life of the family and nation and our entire public life with God's word that does not cease, lasts forever, and does not end either today or tomorrow?"2.

\section{1. "Poland as a Great Common Duty": Personalist-Communitarian Perspective}

Undoubtedly, the personalistic and communitarian concept of Cardinal Wyszyński presented in the socio-political context of post-war Poland deserves attention because of its praxeological specificity. From a personalistic point of view, the key to a proper

2 Stefan Wyszyński, “Pokój jest dziełem sprawiedliwości. Na Boże Narodzenie 25.12.1972”, in: Stefan Wyszyński, Nauczanie społeczne 1946-1981 (Warszawa: ODISS, 1990), 526. 
understanding of the complex structure of social life issues is a justified and verifiable interpretation of the human person. It is expressed on the anthropological and theological level and has its reference to the entire reality of social life, both in the individual and community dimensions ${ }^{3}$. In other words, the most critical link in the whole process of involvement in social life - in all its levels - is its subject and creator, a concrete person who is at the same time the center and goal of all public life, making individual choices and making certain decisions. Hence, when speaking of involvement in public life, it should always be associated with the anthropological criterion, the integrally understood man, in the full truth about himself4. In contrast, "communitarianism" is associated with liberal and conservative ideas, which - as part of the common heritage - emphasize human beings, their rights, and comprehensive development. Communitarianism understood in this way, also refers to Christian personalism, which highlights the issues of the common good, community, and emphasizes the vital role of morality in all dimensions of social lifes.

According to Wyszyński, the breakdown of community and morality is one of our time's main problems. It points not only to the invasion of anti-Christian Marxist-Leninist ideology but also to liberal individualism6 ${ }^{6}$. Liberal-conservative concepts are often seen as promoting individualism at the expense of community, morality, and civic virtues? Nevertheless, in the opinion of many contemporary personalists and communitarists, both

3 Ryszard Ficek, Christians in Socio-Political Life: An Applied Analysis of the Theological Anthropology of Cardinal Stefan Wyszyński Primate of Poland (Torun: Wydawnictwo Adam Marszałek, 2020), 23-37.

4 Stefan Wyszyński, “O katolickiej woli życia. List pasterski na Wielkanoc 1947”, in: Stefan Wyszyński, Nauczanie społeczne 1946-1981(Warszawa: ODISS, 1990), 34-36; Stefan Wyszyński, "Wołanie ludzkości o obecność Kościoła w świecie współczesnym. Warszawa 18.04.1973”, in: Stefan Wyszyński, “Idzie nowych ludzi plemię...”. Wybór przemówień i rozważań (Poznań-Warszawa: Pallottinum, 1973), 93; Stefan Wyszyński, "Kamienie węgielne budowania na górach świętych. Na Jasnej Górze po powrocie z uwięzienia 2.11.1956", in: Stefan Wyszyński, Nauczanie społeczne 1946-1981 (Warszawa: ODISS, 1990), 64.

5 Ryszard Ficek, Zaangażowanie chrześcijan w życie publiczne w kontekście nauczania kardynała Stefana Wyszyńskiego prymasa Polski (Lublin: Gaudium, 2020), 33-41; Clarke E. Cochran, "The Thin Theory of Community: The Communitarians and their Critics", Political Studies 32 (1989): 422-435.

6 The tragic experiences of the past call for an attitude of vigilance. According to the Primate, "nobody in the world is sure of the future. No nation can be guaranteed a "golden age". And we also have no guarantee that Poland will not have to make any sacrifices and powerful ones!" (Stefan Wyszyński, "Bez ofiar i wyrzeczeń nie ma zwycięstwa. Warszawa - kościół Matki Bożej Zwycięskiej 16 VIII 1970”, in: Stefan Wyszyński, Z gniazda orląt (Rome: Papieski Instytut Studiów Kościelnych, 1972), 102). The seriousness of the threats is added by the fact that Poland's post-war situation was not conducive to the moral renewal of the nation. Moreover, it can be stated that the ideological and socio-political conditions that emerged after the war contributed to the increase in moral threats to the nation's life. Therefore, Primate Wyszyński, emphasizing this problem, considers it extremely important and even decisive for a Christian society. Stefan Wyszyński, “«Sursum corda». Z kazania do górali tatrzańskich. Zakopane 1957”, in: Stefan Wyszyński, Wszystko postawiłem na Maryję (Paris: Editions du Dialogue, 1980$), 145$.

7 For Stefan Wyszyński, as for many interpreters of the Christian vision of social life, the primary error of the classical concept of liberal capitalism was the myth based on the assumption that competition and rivalry are the fundamental driving force behind the economic development of the state. Therefore, the Christian vision of truth, in this case, has been contrasted with the moral relativism characteristic of liberal ideology. In other words, Wyszyński defended the legitimacy of shaping an integrated society and functioning in the space of objective moral norms - as opposed to a society built on the principles of social individualism and moral indifferentism. Wyszyński, Miłość i sprawiedliwość, 320; Stefan Wyszyński, “«Homo Dei», I Kazanie Świętokrzyskie 13.01.1974”, in: Stefan Wyszyński, Nauczanie społeczne 1946-1981 (Warszawa: ODISS, 1990), 574-579. 
the influence of Marxist-Leninist ideology and - to some extent - liberal-conservative thought led to an over-emphasis on various types of "human rights" without emphasizing the issue of obligations, which can result in destructive effects throughout the entire society. In their opinion, the reciprocity of "rights and obligations" is a fundamental principle of social justice. Thus, the correct interpretation and balance of "rights and obligations" ensure the community's survival as such ${ }^{8}$.

The mutual conditions between the catalog of "rights and obligations" puts Wyszyński's concept in conflict with both supporters of the "centrally planned economy" (the specificity of real socialism) and liberals who argue that individual economic entities have the right to control social resources and make profits. Rarely do they talk about the obligations of business to society9. The liberal position also emphasizes that the economic subject's sole responsibility is to maximize its own interest. In this sense, the liberal perspective defines a set of individual rights for all individuals. According to supporters of communitarianism, treating the idea of social justice in John Rawls's style results in many different types of rights that generate additional problems in the context of a specific socio-political situation ${ }^{10}$. Both the socio-political context and the poorly emphasized question of citizens' obligations towards the state can lead to severe injustices ${ }^{11}$.

Many contemporary supporters of personalist-communitarian ideas argue that the extension of rights without responsibility and ignoring the socio-political context can lead to the breakdown of a community as well as the emergence of a nation of alienated and isolated social groups and individuals. They are also advocating policies to reverse the destruction of local communities. Therefore, they pay attention to nurturing and supporting the community and its social institutions. Cardinal Wyszyński also talks in a similar vein ${ }^{12}$.

8 Ficek, Zaangażowanie chrześcijan $w$ życie publiczne $w$ kontekście nauczania kardynała Stefana Wyszyńskiego prymasa Polski, 29-32; Amitai Etzioni, The Spirit of Community (New York: Crown Books, 1993), $263-264$.

9 Milton Friedman, Capitalism and Freedom (Chicago: University of Chicago Press, 1962).

10 John Rawls, A Theory of Justice (Cambridge: Harvard University Press, 1971).

11 The vision of the human person and the servant role of society towards man, rooted in the Christian tradition, as understood by Cardinal Wyszyński, is expressed primarily in the concept of the human person's unquestionable primacy in the entire created world, including the complicated reality of social life. "The awareness of the superiority of a person over the community - according to the Primate - saves a person in every system from a juggernaut that destroys the human personality, sometimes taking away all rights, and trying to leave only obligations, or (...) making the rights of a person dependent on the fulfillment of duties". Stefan Wyszyński, "Prymat osoby nad rzeczą. Z okazji 30. rocznicy powstania Wydziału Filozofii Chrześcijańskiej KUL 7.03.1976", in: Stefan Wyszyński, Nauczanie społeczne 1946-1981 (Warszawa: ODISS, 1990), 717.

12 Human rights are one of the main areas of interest of Stefan Wyszyński, who is present in all his work, both scientific and pastoral. Stefan Wyszyński, "O chrześcijańskim wyzwoleniu człowieka. List pasterski na adwent 1946”, in: Stefan Wyszyński, Nauczanie społeczne 1946-1981 (Warszawa: ODISS, 1990), 24-28; Stefan Wyszyński, “O katolickiej woli życia. List pasterski na Wielkanoc 1947”, in: Stefan Wyszyński, Nauczanie społeczne 19461981 (Warszawa: ODISS, 1990), 29-40; Stefan Wyszyński, “«Res sacra homo». Podczas jubileuszu świętego Wincentego a Paulo w Krakowie 27.09.1960”, in: Stefan Wyszyński, Nauczanie społeczne 1946-1981 (Warszawa: ODISS, 1990), 151-156; Stefan Wyszyński, “«Nauczycielu prawdomówny!». Do nauczycieli Warszawy 6.11.1960”, in: Stefan Wyszyński, Nauczanie społeczne 1946-1981 (Warszawa: ODISS, 1990), 168-173; Stefan Wyszyński, "O moralną odnowę narodu. Po ogłoszeniu encykliki «Pacem in terris». Białystok 2.06.1963”, in: Stefan Wyszyński, Nauczanie społeczne 1946-1981 (Warszawa: ODISS, 1990), 212-215; Stefan Wyszyński, 
The family is the most important social institution. Wyszyński advocates introducing a wide range of family support measures, including family leave, adequate wages for breadwinners, enforcement of child support payments, and laws that hinder divorce13. According to Wyszyński, only a stable family with two parents has the best chance of the correct upbringing of a child and moral education. Moral and civic education and religious-ethical renewal are seen as necessary, as is community service. This promotes morality and public virtue and teaches citizenship ${ }^{14}$. Thus, Wyszyński's concept emphasizes the vital role of supporting pro-family policy, including: flexible time; family leave; child benefits; education to instill family and patriotic values; and providing education about family life to potential parents. He also advocates tightening the rules on divorce and changing other laws that they believe have a negative impact on the family.

According to Wyszyński, a severe problem of contemporary societies is the real decline in political participation, as well as the diminishing credibility of the government system in the eyes of the public. Therefore, it is crucial to reform the political system, the aim of which would be to enable more involvement of citizens in political life. First, however, the moral authority of the state administration must be restored. The main problems are corruption, the particular interests of the "ruling class," and the lack of morality in

\footnotetext{
“Zmaganie się sprawiedliwości i miłości. Zwycięstwo miłości. Warszawa - kościół oo. Bazylianów 6.04.1968”, in: Stefan Wyszyński, ,Idzie nowych ludzi plemię...”. Wybór przemówień i rozważań (Poznań-Warszawa: Pallottinum, 1973), 232-237; Stefan Wyszyński, “Głos synodu na temat sprawiedliwości w świecie. Po powrocie z Synodu Biskupów. Warszawa 6.01.1972”, in: Stefan Wyszyński, Nauczanie społeczne 1946-1981 (Warszawa: ODISS, 1990), 477-482; Stefan Wyszyński, "Jakiej chcecie Polski? Do młodzieży akademickiej w Warszawie 22.03.1972”, in: Stefan Wyszyński, Nauczanie społeczne 1946-1981 (Warszawa: ODISS, 1990), 488-493; Stefan Wyszyński, „«W obronie życia Polaków», Warszawa-Leszno 9.03.1975”, in: Stefan Wyszyński, Prymat człowieka $w$ tadzie społecznym (London: Odnowa, 1976), 184-188; Stefan Wyszyński, “Odpowiedzialność - obowiązki i prawa w życiu narodu. Jasna Góra 26.08.1980”, in: Stefan Wyszyński, Nauczanie społeczne 1946-1981 (Warszawa: ODISS, 1990), 948-954; Stefan Wyszyński, "Kościół jest najbliższym sprzymierzeńcem waszych dążeń. Gniezno-Dom Prymasowski 4.02.1981”, in: Stefan Wyszyński, Do „, Solidarności“, Rady i wskazania (Warszawa: Oficyna Naukowa, 1996), 47-56; Stefan Wyszyński, "Prawa osoby ludzkiej w społeczeństwie. Warszawa - kościół św. Anny 18.03.1957”, in: Stefan Wyszyński, Kazania i przemówienia autoryzowane 1956-1981, vol. 1-67, Archiwum Instytutu Prymasowskiego w Warszawie, vol. II, 4-5; Henryk Skorowski, Problematyka praw człowieka: Stadium z nauki społecznej Kościoła (Warszawa: Wydawnictwa Akademii Teologii Katolickiej, 1996), 21; Joanna Kowalska, “Kardynał Wyszyński w walce o człowieka sumienia”, Społeczeństwo 26, 3 (2016): 131-136.

13 The family's high position in the light of the personalistic vision of life and action requires the protection of its fundamental rights and obligations, which enable proper functioning in the entire community of social life. Cardinal Wyszyński speaks about the rights of each person as a family member, emphasizing the rights in the family and the rights of the family as a whole. The very specificity of the family, the richness and variety of tasks require compliance with the entire hierarchy of rights and obligations that enable its proper development and functioning. Bartnik presented a very exhaustive "charter of family rights" based on the teachings of Cardinal Wyszyński. Czesław Stanisław Bartnik, Pedagogia narodowa prymasa Stefana Wyszyńskiego (Lublin: KUL, 2001), 189.
}

14 The community character of the family is expressed above all in the fact that it is a community of love and solidarity, a place where different generations meet - an area of the most profound interpersonal contact, based on love and voluntariness, on the deep and complementary relationship between men and women and the generations that help each other in attaining fuller life wisdom. The institutional nature of the family, in turn, consists in the fact that it is built on the foundation of marriage - it is a legal, economic and social unit and has specific tasks to fulfill. Thus, it is perceived and treated as an institution. However, both dimensions are linked by the fact that their first duty and, as it were, a summary of others, is mutual. Ficek, Zaangażowanie chrześcijan w życie publiczne: w kontekście nauczania kardynała Stefana Wyszyńskiego prymasa Polski, 42-45. 
socio-political life. In supporting majority rule, however, careful attention should be paid to whether they also care for minority rights ${ }^{15}$.

Many issues related to the social control of power structures were brought outside the legal system and dealt with through more informal social supervision methods. That is why Wyszyński favors a cooperation between local communities and not formal social assistance programs ${ }^{16}$. In this case, management programs operating at the local level, taking into account the principles of subsidiarity and subsidiarity, play an essential role. It also promotes the issues of democratization of power structures and participation in social and political life in the spirit of responsibility for the common good. Therefore, it is preferable to activate local self-governments activities focused on mutual assistance in the spirit of the Christian principle of solidarity and subsidiarity.

\section{State: its Essence, Genesis, and Purpose}

One of the fundamental issues raised by Stefan Wyszyński in his teaching is the issue of mutual relations between the state and the national community, as well as the specific principles that condition the proper functioning of both socio-political structures. According to the Primate, "the state gives to the nation «completion» and sovereignty"17. Hence, the state turns out to be "not only a spiritual community, but also a contractual legal convergence"18.

15 Ficek, Christians in Socio-Political Life: An Applied Analysis of the Theological Anthropology of Cardinal Stefan Wyszyński Primate of Poland, 255-259.

16 Ficek, Zaangażowanie chrześcijan w życie publiczne: $w$ kontekście nauczania kardynała Stefana Wyszyńskiego prymasa Polski, 268-272.

17 Wyszyński, Miłość i sprawiedliwość społeczna, 149. Taking into account the specificity of the People's Republic of Poland, it is difficult to consider the post-war People's Poland (1944-1989) as a sovereign state, which political system - according to all socio-political and economic standards - could be regarded as a form of socialism typical of the "Eastern Bloc" countries under the political domination of the Soviet Union. In other words, the entirety of the principles of organization and operation of state power in post-war Poland was practically identical for all socialist countries, despite different solutions in the field of building the state apparatus or socio-economic conditions of the country. These principles defined the socio-cultural and political structure of the state understood as a "class" arrangement of the state and thus answered the fundamental question: in whose hands is the state power? In practice, a characteristic feature of the socialist system was the use of communist phraseology emphasizing the notion of "social class", "class struggle," as well as - typical for communist ideology - the "economic base and cultural superstructure" model as well as the category of socio-economic determinism. As a result, the entire political narrative was demagogic and fit into the twisted Marxist dialectics sphere. Moreover, the specificity of the political system in force in post-war Poland largely exhausted the features characteristic of authoritarian regimes. The reality of "real socialism" was similar to systems characterized by limited political pluralism, little responsible for the so-called "common good." Indeed, there were administrative structures and parliamentary institutions characteristic of a democratic system that could inspire confidence. However, a more detailed analysis of them shows that they did not have much in common with the democratic system in the sense of the standards typical of mature democracies of Western countries. Ficek, Christians in Socio-Political Life: An Applied Analysis of the Theological Anthropology of Cardinal Stefan Wyszyński Primate of Poland, 223-246; Eva Erman, Anders Uhlin, Legitimacy Beyond the State? Re-examining the Democratic Credentials of Transnational Actors (New York: Palgrave Macmillan, 2010), 6-13.

18 Wyszyński, Miłość i sprawiedliwość społeczna, 181. Taking into account the complex issues of socio-political praxis, Wyszyński states: "Nowadays everyone expects great spiritual virtues from those in power. Tired of 
According to Cardinal Wyszyński, the political order of society depends primarily on its goal. If this goal is the "common good" understood as the creation of values and conditions for the full personal development of man and the entire society, then this function can be performed by the state. It is only the state; therefore, that is a perfect and complete community in the sense that it is self-sufficient in meeting the development needs of its own citizens. In this context, Wyszyński understood the state "as a community arises out of the needs of innate human cohabitation ${ }^{19}$. It must aim to create such conditions, a system in which life would develop as much as possible. It would allow people to live a good life and fulfill all personal and social duties" 20.

In this sense, however, the purpose of the state's existence is the desired state of reality, the cause of which is the introduction of some form of social organization. In other words, the state exists because there is a particular, better or worse, desired state, the achievement of which would otherwise be impossible (that is if the state did not exist), or considerably more difficult. So, the goal and destiny of the state is the common good of the entire nation and its all citizens. Thus, the state, identifying itself with the "common good" of the national community, has the errand of supporting various forms of citizens' participation in public life, in which there is a specific division of functions, rights, and obligations $^{21}$.

The functions of the state are methods and directions of activities thanks to which it can achieve the assumed goals. It follows, however, that a single goal can be completed in different ways (i.e., with another distribution of efforts and resources among certain functions). "The point is that the state community should act for the common good of

democratic irresponsibility, more than experienced with secular morality without any moral principles, with the politics of dirty business and dirty hands, we demand Christian morality for public life". Wyszyński, Miłość i sprawiedliwość społeczna, 150.

19 Wyszyński, Miłość i sprawiedliwość społeczna, 335.

20 Wyszyński, Miłość i sprawiedliwość społeczna, 355-336.

21 Stefan Wyszyński, "Naród - Kościół - Państwo. Kazanie świętokrzyskie (25.01.1976)”, in: Stefan Wyszyński, Nauczanie spoleczne 1946-1981 (Warszawa: ODISS, 1990), 713. With the takeover of power by the communists and the implementation of the public centralized command and distribution system, the importance of local administrative structures also weakened. Leaders of centralized state structures did not want to tolerate the uncontrolled concentration of political power that was beyond the direct reach of the supreme party organs. Therefore, all forms of local administration characterized by the autonomy of action were considered a threat that undermined the integrity and unanimity of the adopted political strategy. Consequently, all institutions operating at the local communities' level were gradually marginalized or replaced by offices under the party authorities' direct control. When the regional party centers, legislative power, and local self-government structures were losing power to the executive bodies, a similar process also affected the judiciary. Although in countries characterized by a mature and stabilized parliamentary tradition, the judiciary - at least officially - does not play an active political role. It still remains an essential element of the state's systemic framework. Its primary function is expressed in maintaining the legal order. Therefore, all spheres of social life - including also the judicial dimension - must respect the judgments of the judiciary. In the context of the post-war reality of the PRL, even the judiciary was mostly dependent on the centralized structures of the communist party elites. Renate Mayntz, "Legitimacy and the Directive Capacity of the Political System", in: Stress and Contradiction in Modern Capitalism: Public Policy and the Theory of the State, ed. Leon N. Lindberg (Lexington: Mass., Lexington Books, 1975), 277-279; Peter Fabienne, "Legitimate Political Authority and Expertise", in: Legitimacy: The State and Beyond, eds. Wojciech Sadurski, Michael Sevel, Kevin Walton (New York-London: Oxford University Press, 2019), 32-40. 
all citizens when it takes into account the social pluralism of workers, farmers, and the intelligentsia. Moreover, the point is that the state should not be afraid of the greatness of man, who is the highest value after God, regardless of the system in which he lives"22.

In almost universal consciousness, however, the state is treated as the primary form of organization of social life. The contemporary political discourse also emphasizes that the concept of "state" refers to one of the fundamental political categories. Undoubtedly, the post-war idea of the Polish state reflected, but also directly influenced, the specificity of the socio-political transformation of the political system. Therefore, it also shaped the functioning of the multi-dimensional reality of the country.

For political science, however, the state is understood primarily as a type of political society, which includes a set of political norms and a social community occupying a specific territorial area, subordinated to one center of sovereign political power ${ }^{23}$. Taking into account the particular conditions of post-war Poland, it is worth in this context to recall the classic definition of the state proposed by Max Weber. He defined the state as "a legally recognized community that is compulsorily subject to the jurisdiction of the judiciary, uses permanent organizational structures and maintains a monopoly of coercion within its territory and inhabiting it people, including all activities taking place within its jurisdiction" 24 .

In the context of the above analysis, however, there is also the question of the definition regarding the state itself, which, contrary to appearances, is not obvious at all. It is often assumed that the state means a political form of sovereignty over a specific geographical area. Such a definition, however, is flawed, because it refers to the notion of politics, which is equally difficult to define and then identifies the state with its territorial authority (which pushes the idea of the state of nomadic peoples and the itinerant tribal organization beyond the boundaries). On the other hand, it de facto corresponds to the state in the common understanding (although it does not refer to its organs, legitimacy, etc.) ${ }^{25}$.

One can also refer to the idea of the de jure state, i.e., understood in legal terms. There is a generally accepted definition of a state adopted at the Montevideo Convention in 193326: a state is an entity with four distinguishing features: (1) a permanent population; (2) specified territory; (3) government (authorities); (4) the ability to connect with other states. Another definition states that the state is a socio-political organization endowed

22 Wyszyński, "Naród - Kościół - Państwo. Kazanie świętokrzyskie” (25.01.1976), 711.

23 The above term refers to sociological definitions which perceive the state primarily as a social group. It consists of three basic elements: society, territory and power (cf. Andrzej Antoszewski, Teresa Łoś-Nowak, "Państwo", in: Leksykon politologii, red. Andrzej Antoszewski, Ryszard Herbut (Wrocław: Wydawnictwo Uniwersytetu Wrocławskiego, 1995), 261).

24 Max Weber, Economy and Society (Los Angeles-London: Berkeley, 1978), 39.

25 Brian Nelson, The Making of the Modern State: a Theoretical Evolution (New York: Palgrave Macmillan, 2006), 108-124.

26 Hersch Lauterpacht, Recognition in International Law (New York: Cambridge University Press, 2012 ), 419. 
with sovereign power, and is also a territorial as well as compulsory (formalized) organization $^{27}$.

Concern for the future of society and the development of the right structures of socio-political life, thus, requires a rediscovery of human and moral values, belonging to the very essence and nature of man, which result from the truth about man and express and protect the dignity of the human person: values, thus, which no individual, no majority or any state can create, change or destroy, but which should be recognized, respected and strengthened 28 .

\section{PRL's "People's Democracy" as an Example of a Dysfunctional Socio-Political System}

Along with the systemic transformation of the post-war People's Poland and the change of the paradigm of power, there was an ideological offensive in the communist spirit aimed at changing the previously binding standards and principles of social and political life, as well as "remodeling" the worldview and mentality of Poles based on the concept of a "new socialist morality" rooted in the ideals of the materialist Marxist-Leninist philosophy. Official propaganda emphasized the importance of pluralism and democracy but understood only in terms specific to communist ideology, the so-called "People's Democracy" wholly subordinated to the totalitarian system of power. The interdependence between "people's democracy" and socialism was, therefore, a central dimension of the efforts to implement the political assumptions of the Polish People's Republic.

It would be a truism then to utter that authentic democracy is possible only in a state ruled by law and based on a correct concept of the human person ${ }^{29}$. In a similar tone, spoke out Wyszyński: "As citizens of this country, we can get the effort to make real democracy happen in Poland! It has been in the traditions of the Polish nation since royal times" 30.

However, taking into account the post-war situation of Poland, it is not easy to recognize the political profile of the PRL as acceptable and compatible with the standards adopted by Catholic social teaching. Moreover, the whole concept of "people's democracy" can be described as a specific form of the so-called "confused democracy," which is characterized by quite serious discrepancies associated with the establishment of essential criteria and principles constituting the specificity of the democratic system ${ }^{31}$. The main problem

27 Erika Cudworth, The Modern State: Theories and Ideologies (Edinburgh: Edinburgh University Press, 2007), $45-47$.

28 Zbigniew Borowik, "Wspólnota państwowa w nauczaniu Kardynała Stefana Wyszyńskiego", Życie Katolickie 7-8 (1984): 147.

29 John Paul II, “Centessimus annus”, n. 46, access 27.08.2020, http://www.vatican.va/content/john-paul-ii/en/ encyclicals/documents/hf_jp-ii_enc_01051991_centesimus-annus.html.

30 Stefan Wyszyński, „Apel Prymasa Polski ze stolicy. Do wszystkich dzieci Wspólnej Ojczyzny (Warszawa, 25.12.1970)", in: Stefan Wyszyński, W sercu stolicy (Warszawa: Soli Deo, PAX), 156.

31 Political decision-making centers were moved from the civic community, peripheral state institutions, and concentrated within a narrow group aspiring to be the executive power (the executive of the communist party of the 
of political struggle was not so much the answer to the question: should the state be democratic or not. The primary dispute touched the issue of understanding democracy as such. It was also connected with the choice of an appropriate political strategy, which - as a consequence - would enable the realization of Marxist-Leninist political assumptions ${ }^{32}$.

From a personalistic point of view, however, the most desirable systemic solution is a Western-style parliamentary democracy. However, Cardinal Wyszyński realizes that both in classical and modern concepts of the socio-political order, democracy was not always treated as the best solution. The answer to the shortcomings of liberal democracy should, according to the Primate, be "personalistic democracy". The concept of democracy understood in this way accepts human rights and the need to distinguish three types of power in the state community. However, it postulates other principles of political life: personalism, the "common good", and respect for moral norms. What significantly differentiates personalist democracy from liberal democracy is the rejection of the axiological neutrality of the state and the interpretation of the political society as a community ${ }^{33}$.

Personalist democracy is, therefore, a community democracy, and consequently, it combines freedom with ethical responsibility 34 . In other words, the personalistic concept proposes that instead of undermining the value of democracy, give it an axiological character, so that it is not only a collection of procedures and institutions but also creates bonds based on values. Among the various historically developed models of democracy, a parliamentary democracy based on civil society is the most appropriate for modern

Polish United Workers' Party). In turn, referring to the typology of participation in organizational systems, one can indicate "instrumental-calculative" motives, i.e., coercion and faith in common values as categories stabilizing the political system. However, within this kind of typology, only the latter form of motivation - referring to axiological sources - would create a possible option to legitimize power. Admittedly, political practice proves that the parliaments of all countries in the world delegate some power to government executive structures. It must be admitted, however, that in the post-war reality of Poland, the specificity of this process was quite bizarre. It meant that even the Sejm - the supreme organ of the Polish legislature - often turned out to be merely a mere addition to the executive power which remained in the hands of the communist party elite. Giovanni Sartori, The Theory of Democracy Revisited (Chatham: Chatham N.J., 1987), 6; Wojciech Sokół, Legitymizacja systemów politycznych (Lublin: Wydawnictwo UMCS, 1997), 11-12.

32 Local self-government structures were subordinated to the state administration, directly subordinated to the headquarters in Warsaw. Such essential dimensions of social life as education, health care, maintenance of transport infrastructure, and taxes were taken over by managing regional administrative structures that adopted directives and commands from their superiors from the Central Committee of PZPR. As a result, a very strongly emphasized element of the state's political strategy had become the so-called "nationwide interest", rather than initiatives of local administration centers. It resulted from the political concept of action adopted by the central structures of state power, which aimed at taking control over the whole decision-making process, both in the macro and micro-social dimensions. Sokół, Legitymizacja systemów politycznych, 32-39.

33 Explaining the stability and duration of the so-called "undemocratic structures" of the communist state, one can refer to such sources that legitimize the political system, such as high intensity and high range of violence, unreflective consent based on habituation or institutional fit. It means above all self-enslaving of personality in institutional collectives and "mass loyalty" towards the official order resulting from the inability to implement alternative visions of charge, or also from the lack of such concepts. Michael Mann, "The Ideology of Intellectuals and Other People in the Development of Capitalism", in: Stress and Contradiction and Modern Capitalism, ed. Leon N. Lindberg (Lexington: Mass, 1975), 278; Jan Pakulski, "Legitimacy and Mass Compliance: Reflection on Max Weber and Soviet-type Societies”, British Journal of Political Science 16 (1986): 451-472.

34 Stanisław Kowalczyk, U podstaw demokracji: Zagadnienia aksjologiczne (Lublin: RW KUL, 2001), $146-158$. 
nation-states. It is not the only representative but also participatory ${ }^{35}$. The rules of social coexistence, the goals pursued and the means adopted for their implementation are determined not only by the quantitatively understood will of the majority but also take into account the criteria of good and truth applicable in a given community.

However, taking into account the post-war situation of Poland, it is difficult to consider the political profile of the Polish People's Republic as an acceptable model of any form of Western-style "democracy", as well as a political system consistent with the standards adopted by Catholic social science. Moreover, the entire concept of "people's democracy" can be defined as a specific form of the so-called confused democracy. It was characterized by quite serious discrepancies related to the establishment of the essential criteria and principles constituting the specifics of a democratic system ${ }^{36}$. The fundamental problem of political struggles concerned not so much the answer to the question: should the state be democratic or not? He touched upon the issue of understanding democracy as such, and it was also connected with the choice of an appropriate strategy of political actions, which, as a consequence, would make it possible to implement the socialist political assumptions in the specific political and social conditions of post-war Poland ${ }^{37}$.

In other words, the repeated issue in socialist systems of "extending" democratic rules from the political to the social sphere was primarily economic ${ }^{38}$. The introduction of a dummy of "people's democracy", modeled on the liberal concept of "bourgeois democracy", facilitated the achievement of the basic assumptions of the socialist system in Poland. Thus, the development of democracy made it possible to achieve socialist goals related to the issue of social integration, equality, and mutual cooperation. Therefore, the fight for "people's democracy" turned out to be necessary for the context of the struggle for socialism: one could not exist without the other. In summary, one can quote the statement by Frank Cunningham. He emphasized that while socialism was necessary to develop the

35 Social personalism prefers the model of a democratic state, but democracy can be twofold: representative and participatory. Representative democracy is achieved through participation in parliamentary elections and possibly plebiscites. This kind of political democracy is indispensable but not sufficient. There is also a need for participatory democracy, which is realized through various types of local governments. The final form of democracy is continuous, not a one-off and purely formal act (cf. Kowalczyk, U podstaw demokracji: Zagadnienia aksjologiczne, 171-172).

36 Sartori, The Theory of Democracy Revisited, 6.

37 In a political environment where such a strong position characterized the executive power, the law was very often treated instrumentally and arbitrarily. Both the political elite, as well as senior officials of the bureaucratic apparatus, were somewhat reluctant to comply with regulations in force if it affected their particular interests. In other words, the law became a reality less binding on the power elite - while society was obliged to submit to its principles rigorously. The centralization of state administration structures made the mutual ties connecting the state with the civic society seriously falsified. Thus, the fundamental element linking the rulers and the ruled has become - a kind of clientele, functioning on the principle of redistribution of offices, positions, and various types of material resources available to the state. Analyzing the problems of political clients in the conditions of a socialist state, it can be described as a kind of "relation of exchange between inequalities". Ryszard Ficek, Christians in Socio-Political Life: An Applied Analysis of the Theological Anthropology of Cardinal Stefan Wyszyński Primate of Poland (Torun: Wydawnictwo Adam Marszałek, 2020), 263-265.

38 Adam Przeworski, Capitalism and Social Democracy (Cambridge: Cambridge University Press, 1985), 7. 
so-called "people's democracy", "people's democracy" facilitated the achievement and security of the gains of the socialist system ${ }^{39}$.

However, discussions related to the issue of adopting an appropriate concept of socialist democracy - relevant to the social and political conditions of the socialist state continued throughout the entire period of the political transformation of the People's Republic of Poland. According to the ideologues of the system, "people's democracy" was inextricably linked with principles such as democratic centralism and the planning system, and must fit within the framework of the system typical of a socialist state in Soviet edition, the functions of which result from both internal tasks and international conditions.

In "socialist democracy", therefore, there is no room for political pluralism. According to Communist decision-makers, within the framework of the Marxist-Leninist system, there is no objective class basis, as well as the need for pluralist institutionalization of political differences and platforms. However, there is a need, and there are conditions for a real discussion of social problems and methods of solving them, a discussion aimed at elaborating optimal programs and decisions and, on this basis, achieving the broadest range of unanimity in deciding and acting. Under the socialist political system - whose center and motor force is the Communist Party of the working class - conditions are created for the development of indirect and direct democracy, for a vibrant and compelling political life ${ }^{40}$.

The basis for the justification of the "people's democratic" system was the so-called heteronomous-teleological legitimization. It was an example of combining an ex-situ argument (referring to factors external to the authorities) with the argument ex motu et virtute, which contains a teleological element that is, referring to changes that the government introduces and will to introduce ${ }^{41}$. Such heteronomous legitimacy is identical to the category of numinous legitimacy: just as in theocratic political systems, where government legitimacy derives from the "chosen by divine power enlightened guru" (here, communist party elites) ${ }^{42}$.

39 Frank Cunningham, Democratic Theory and Socialism (Cambridge: Cambridge University Press, 1987), 25.

40 Zbigniew Rybicki, Andrzej Werblan, “Historyczne miejsce demokracji socjalistycznej”, Państwo i Prawo 8-9 (1977): 23-38. However, the promised benefits associated with the functioning of the socialist system of the political system had never been materialized. Lack of alternative opposition activity, political patronage of the functioning party elites offered in place of the actual representation of the civic community, as well as clientelism, which could not function without the exploitation of clientele by its patrons - all this significantly affected the degeneration of the existing political system. It must be admitted that the Communist elite of the PRL primarily preyed on the vulnerability of the civic community. The implemented political practice was, therefore, difficult to reconcile with the concept of social egalitarianism promoted by communism. Centralized state administration was also unable to create sufficiently strong and effective governance structures. A stable system of government performs primarily the needs and interests of the community citizen union, expecting - simultaneously - its support and legitimacy for the current strategy of political life. Paul Lewis, Eastern Europe: Political Crisis and Legitimation (London-Sydney: Croom Helm, 1984), 19-36.

41 Georg Brunner, "Legitimacy Doctrines and Legitimation Procedures in East European Systems", in: Political Legitimation in Communist States, eds. T.H. Rigby, Ferenc Feher (New York, 1982), 34-35.

42 Reiner Sternberger, "Legitimac", in: International Encyclopedia of Social Science, vol. IX, ed. David E. Sills (New York, 1989), 244-246. 
The reference to such entitlements to holding power turns out to be more important than autonomous-consensual legitimization, which refers to arguments such as: "this power comes from a properly concluded contract". Over here, the principle of people's sovereignty is particularly stressed. In other words, the mere fact of referring to the above legitimacy doctrines turns out to be insufficient for the so-called normative legitimacy. Achievement of the so-called actual legitimacy - empirically determined - requires the use of appropriate political procedures by the political elite, which are understood as methods of adapting normative legitimacy to real differences for heteronomy-teleological legitimization and autonomic-consensual legitimacy. Concerning the specificity of the Communist political system, the former reasoning is the most important. Amongst them are, e.g., touting and propaganda carried out through manipulation and social engineering, education as well as mass media. In turn, autonomous-consensual legitimization procedures are elections and certain forms of direct democracy that create the illusion of the implementation of the principle of people's sovereignty ${ }^{43}$.

According to the assumptions of the Communist ideologues, the concept of people's democracy assumed that the communist party represented the interests of all social groups in the state. Moreover, all particular political activities - following this principle should be subordinated to the general will of all (i.e., Communist party). As a result, the autonomy of organizations representing the interests of individual social groups was replaced by a kind of "corporate agreement", joining the above institutions with the communist party structures. Such changes were perceived as an essential step towards "people's democracy" because they made it possible to subordinate particular interests as the "will of the people" 4 .

43 In other words, it was a form of mutual cooperation - in a sense based on mutual benefits - between the power elites and the rest of society, which generally was deprived of significant influence on the political life of the country. The elites of the communist authorities usually offered their political clients public offices and positions (combined with the possibility of obtaining adequate earnings and access to government administration structures), a sense of security, and material means. In response, the political client undertook to show support, respect, and loyalty. This, in turn, helped legitimize the high position of the power elites. In this sense, clientelism was not only a form of political contract, but it was a kind of political channel that - at least to some extent - connected civil society with the communist elite of power. Christopher Clapham, "Clientelism and the state", in: Private patronage and public power, ed. Christopher Clapham (London: Palgrave Macmillan, 1982), 4-6; Fabienne, "Legitimate Political Authority and Expertise", 41-42.

44 In the case of the People's Republic of Poland, centralized structures of state power quite quickly led to the "falsification" of most of the ties linking the state with civil society. Institutions that could constructively influence the ongoing socio-political changes - suggesting alternative solutions, or playing the role of the so-called "safety valve" in the event of possible disputes and misunderstandings were gradually marginalized. In their place, institutions strictly dependent on a narrow group of the apparatus of power were established, which in the performance of its tasks relied primarily on its own consultations and expert opinions. Perhaps it allowed for more effective, at least in the view of party elites, implementation of the assumed socialist concept. However, this was the reason not only for the slow alienation of the power elite but also for the emergence of a serious breach between the structures of state administration and civil society. No wonder then that Primate Wyszyński approached the institutions of the socialist state with great caution, and focused his attention on the "Nation". However, he recognizes the fact that the state as the political and organizational structure of the Nation is of fundamental importance and has the right to exercise supreme power over the citizens and the communities inhabiting its territory. Nevertheless, "as a community, it grows out of deep needs inherent in human nature". Stefan Wyszyński, Miłość i sprawiedliwość społeczna (Poznań: Pallottinum, 1993), 335. 
Theoretically, the "democratic" character of the Communist Party as "the leading force of the nation" was to be secured by several factors. These included, among others: the mass character of the party; the right of its members to freely choose party leaders; representation of various social groups not associated in the party ranks, nonetheless engaged in political activities in non-party organizations of a mass character; the right of all voters to choose their own party representatives who could be suitable candidates for power structures, both at the local and central level45.

Once again, however, it turned out that in the specific political reality of the Polish People's Republic, the theory did not have much in common with real life.

\section{A Call for the "Democratization" of Socio-Political Life}

Undoubtedly, Primate Wyszyński was aware of the gravity of the situation in which Poland found itself in the post-war period. In this sense, his teaching was part of the broader context of Catholic social teaching, which emphasized that all nations are free to choose the political system of the state. Any system, in principle, is acceptable, but on condition that it protects the development of "common good" 46 . Nevertheless, especially in the face of the horrific experiences of World War II and the expansion of the ungodly Marxist-Leninist ideology in the post-war period, the preservation of the Church's neutrality in the subject of the political system proved to be insufficient. Therefore, referring to the words of Pius XII, "true and sound democracy" responds to the circumstances of the present times ${ }^{47}$.

45 In the context of post-war history, however, it is difficult to agree with the opinion that the Polish People's Republic exhausted all components of the rule of law and the democratic control exercised by civil society. Therefore, according to the Primate, the socialist state as a political structure carries out its tasks in the reality of the Nation. Nevertheless, its functions, concerning national life, are often much distorted, and, as a result, of secondary importance. In this sense, the existence of a Nation without a state, although complicated and full of numerous imperfections, seems to be possible and - sometimes - even necessary. An example of this is the period of partitions when the Polish nation was deprived of its statehood. Nevertheless, it was also a time when the national community developed a form of "spiritual state": "a state of genuine national depth". As Cardinal Wyszyński stated: "We see various motives for fighting the truth. First, it is the fear that engulfs people in power. (...) But there may be other arguments in the fight against the truth because the truth is great, huge and can suppress small brains. It is huge, so there may be many arguments against it. The greatness of the truth is terrifying. It hides «gram» truths, tiny departmental accomplishments, minimal achievements, seemingly imperceptible under a microscope, or any other technical device. It is so enormous and inexhaustible that it exceeds human capabilities (...). Therefore, there are many motives to fight the truth; there are great truths, magnificent, tall and small, tiny, transitional, opportunistic, as a human being. For Herod, the truth is a toy, for Pilate - a threat to order, for Judas - a handful of silver coins, for Magdalena - penitential tears, for Mary - swords of sorrow. One pays for the truth for who he/she is. The price of truth is what a man can do, and he sells it for what he can afford. The dispute of the truth will always go on” (Stefan Wyszyński, “"Abyście byli synami światłości». Do naukowców Warszawy (21.03.1959)”, in: Stefan Wyszyński, Nauczanie społeczne 1946-1981 (Warszawa: ODISS, 1990), 124).

46 Leo XIII, "Diuturnum" (29.06.1881), access 27.08.2020, http://w2.vatican.va/content/leo-xiii/en/encyclicals/documents/hf_1-xiii_enc_29061881_diuturnum.html; Leo XIII, “Libertas” (20.06.1892), access 27.08.2020, https:// www.vatican.va/content/leo-xiii/en/encyclicals/documents/hf_1-xiii_enc_20061888_libertas.html.

47 Pius XII, “Orędzie radiowe wygłoszone w wigilię Bożego Narodzenia 1944 r.”, Acta Apostolicae Sedis 37 (1945): $5-23,36$. 
All subsequent statements of the Holy See, therefore, indicated a change in the Church's optics regarding the vision of social and political life. That is why Primate Wyszynski focused his attention not on the structure and organization of internal public life in the post-war reality of the PRL, but a human person. In his understanding, man cannot be regarded as an object or as a passive element of socio-political life but should be considered as "(...) the subject, basis, and purpose of this life" 48 . This point of view also applies to the state whose fundamental sense of existence - as a political community - lies in the fact that the whole society that creates it, in this case, a particular "Nation", becomes a master and ruler of its own destinies ${ }^{49}$.

It is not surprising that the entire teaching of Primate Wyszyński emphasized the multi-faceted dimension of Christian involvement in building just structures of socio-political life. However, the main emphasis was placed on renewing the "conscience of the Nation". In the context of the post-war situation of Poland, it was a condition sine qua non of the moral order determining the stability and proper functioning of the entire state's reality.

Referring to the actual documents of the Church concerning Catholic social teaching, Cardinal Wyszyński formulates the basic principles that condition the functioning of democracy. They mainly include:

(1) The right to life (in this context, Wyszyński emphasizes that its integral part is the right to life and development of the child in the womb from the moment of conception). The right to live in a family.

(2) The right to live in a morally safe environment (suitable for the growth and upbringing of the child).

(3) The right to develop one's own intelligence and freedom (the environment of truth and freedom).

(4) The right to work.

(5) The right to have a family.

(6) The right to religious freedom ${ }^{50}$.

48 Pius XII, “Orędzie radiowe wygłoszone w wigilię Bożego Narodzenia 1944 r.”, 5-23.

49 Jacques Maritain, “Chrześcijaństwo i demokracja”, Znak 4 (1992): 45-47.

50 Stefan Wyszyński, “O chrześcijańskim wyzwoleniu człowieka. List pasterski na adwent 1946”, in: Stefan Wyszyński, Nauczanie społeczne 1946-1981 (Warszawa: ODISS, 1990), 24-28; Stefan Wyszyński, “O katolickiej woli życia. List pasterski na Wielkanoc 1947”, in: Stefan Wyszyński, Nauczanie społeczne 1946-1981 (Warszawa: ODISS, 1990), 29-40; Stefan Wyszyński, “«Res sacra homo». Podczas jubileuszu świętego Wincentego a Paulo w Krakowie 27.09.1960”, in: Stefan Wyszyński, Nauczanie społeczne 1946-1981 (Warszawa: ODISS, 1990), 151-156; Stefan Wyszyński, “«Nauczycielu prawdomówny!». Do nauczycieli Warszawy 6.11.1960”, in: Stefan Wyszyński, Nauczanie społeczne 1946-1981 (Warszawa: ODISS, 1990), 168-173; Stefan Wyszyński, “O pokoju na ziemi. Po ogłoszeniu encykliki «Pacem in terris». Białystok 2.06.1963”, in: Stefan Wyszyński, Nauczanie społeczne 1946-1981 (Warszawa: ODISS, 1990), 212-215; Stefan Wyszyński, "Zmaganie się sprawiedliwości i miłości. Zwycięstwo miłości. Warszawa - kościół oo. Bazylianów 6.04.1968”. In: Stefan Wyszyński, “Idzie nowych ludzi plemię..." (Poznań: Pallottinum, 2017), 232-237; Stefan Wyszyński, "Głos synodu na temat sprawiedliwości w świecie. Po powrocie z Synodu Biskupów. Warszawa 6.01.1972”, in: Stefan Wyszyński, Nauczanie społeczne 1946-1981 (Warszawa: ODISS, 1990), 477-482; Stefan Wyszyński, „Jakiej chcecie Polski? Do młodzieży akademickiej w Warszawie 22.03.1972”, in: Stefan Wyszyński, Nauczanie społeczne 1946-1981 (Warszawa: ODISS, 1990), 488-493; Stefan Wyszyński, "Stawiamy na rodzinę. Do referentek poradnictwa rodz- 
Therefore, according to Wyszyński, only on this basis real democratization of the social and political life structures is possible. "It is in Christ that all men are brothers and are equal in Him because they were created in the image and likeness of God. They are children of God called to eternal happiness. Therefore, by building on Jesus, everything that harms the state prevails, and the common good of all social classes are promoted ${ }^{51}$.

It requires, however, taking into account two fundamental elements:

(1) The servile character of state power.

(2) The possibility of participating in free elections - and thus, enabling the Catholic society to authentic participation in socio-political life, following its Christian system of values ${ }^{52}$.

In other words, the servile nature of all power - also in the dimension of state structures - has its roots in the Catholic social teaching, based on "Jesus Christ, the Eternal Word, God's Word, living in the church, God's Word, by God's Word the work of the Holy Spirit"53. It also underlines the Catholic concept of the Church understood as a community "God's People" for whom "there are no social strata because everyone is compensated by baptism, the Gospel, the Eucharist, prayer, and blessings. All are classless, despite the hierarchy and the people. The hierarchy itself is taken from the people and established for it, in what belongs to God. This means that the nature of the hierarchy, i.e., power, should not be ruling, but serving" 54 .

In this sense, the principles governing democracy should be viewed in ethical terms. They emphasize respect for the dignity of the human person, which is the source of the concept of equality, understood on the level of the spiritual life, as equality with the Creator. Each person should be treated with the respect due to beings created in the image and likeness of God. In other words, the essence of democracy is not based on the principle of the importance of the majority, but on the concept of personalism and the conviction that lay Catholics can direct themselves, and especially to choose those who, based on the virtue of wisdom, can reliably exercise power and respect their natural rights. The above principles constitute the conditio sine qua non of "authentic democracy", which is only possible under the rule of law and based on a correct conception of the human person ${ }^{55}$.

The civic society organizes this cooperation to serve the development of all its members through the selection of administrative and government structures - both at the local and central levels - which are to guide citizens on their behalf for their common good. Therefore, the political consequence of the principle of solidarity is citizens' responsibility

innego w parafiach. Gniezno 6.02.1973”, in: Stefan Wyszyński, Prymat człowieka w ładzie społecznym (Londyn: Odnowa, 1976), 55-65.

51 Wyszyński, "Głos synodu na temat sprawiedliwości w świecie. Po powrocie z Synodu Biskupów. Warszawa 6.01.1972”, 479.

52 Stefan Wyszyński, "Sumienie prawe u podstaw odnowy życia narodowego. Do wiernych (Warszawa, 6.01.1981)”, in: Stefan Wyszyński, Nauczanie społeczne 1946-1981 (Warszawa: ODISS, 1990), 993.

53 Wyszyński, "Sumienie prawe u podstaw odnowy życia narodowego. Do wiernych (Warszawa, 6.01.1981)”, 994.

54 Wyszyński, "Sumienie prawe u podstaw odnowy życia narodowego. Do wiernych (Warszawa, 6.01.1981)”, 994.

55 John Paul II, “Centessimus annus”, n. 46, access 27.08.2020, http://www.vatican.va/content/john-paul-ii/en/ encyclicals/documents/hf_jp-ii_enc_01051991_centesimus-annus.html. 
for decisions of the governing bodies regarded as their representative bodies. Of course, this is indirect responsibility, because it cannot be treated as either successes or failures of people who manage the structures of public life ${ }^{56}$.

In the context of the post-war socio-political reality of Poland, the teaching of Primate Wyszyński promoted a democratic style of government based not on violence, strength or fear, but persuasion and recourse to conscience. This style of government also allows participating in free elections. Thus, participation in free elections is one of the main elements of the state's democratization. In this sense, every citizen is obliged to actively engage in shaping the structures of public life by participating in the elections of authorities' representatives. It is worth noting here that a Catholic is also obliged to select candidates for public offices according to a strictly defined ethical criterion, rooted in the Christian system of values ${ }^{57}$. In other words, the more the state system is close to democratic ideals, the more the duty of citizens to take an active part in manifestations of public life, exercising rights and fulfilling civic duties increases ${ }^{58}$.

Summing up, in the entire teaching of Cardinal Wyszyński, one can notice a clear, albeit restrained, promotion of the democratic political system. The above restraint stemmed from the Primate's anti-model way of thinking and the meta-political attitude of the Church, which - according to him - should deal with the particular political reality. In this way, the "perspective of Catholic social science" avoids demonizing or deifying "democracy" as such. Moreover, the doctrine of the Church neither recommends nor approves any particular form of government (autonomy of earthly reality). Furthermore, every form of the system is good, as long as it does not contradict the Church's doctrine.

Therefore, democracy understood as a system of exercising power is to serve primarily the implementation of the basic assumptions arising from the Christian values which - in essence - coincide with the goals of authentic democracy: personalism, the idea of the common good, the principle of subsidiarity. Thus, integration of democracy into a comprehensive Catholic vision of socio-political reality is to serve to build a free and solidary society centered around man and his inalienable rights, as well as on proper relations between individuals, community, and the state 59 .

56 John XXIII, “Mater et Magistra”, n. 96, access 27.08.2020, http://www.vatican.va/content/john-xxiii/en/ encyclicals/documents/hf_j-xxiii_enc_15051961_mater.html; Paul VI, "Populorum progression", n. 47, access 27.08.2020, http://www.vatican.va/content/paul-vi/en/encyclicals/documents/hf_p-vi_enc_26031967_populorum. html; John Paul II, "Reconciliatio et paenitentia", n. 16, access 27.08.2020, https://w2.vatican.va/content/johnpaul-ii/en/apost_exhortations/documents/hf_jp-ii_exh_02121984_reconciliatio-et-paenitentia.html; John Paul II, “Sollicitudo rei socialis", n. 38, access 27.08.2020, http://www.vatican.va/content/john-paul-ii/en/encyclicals/documents/hf_jp-ii_enc_30121987_sollicitudo-rei-socialis.html; Berhard Sutor, Etyka polityczna. Ujęcie całościowe na gruncie chrześcijańskiej nauki społecznej (Warszawa: Kontrast, 1994), 42-43.

57 Stefan Wyszyński, “Apel Prymasa Polski ze stolicy. Do wszystkich dzieci wspólnej ojczyzny (Warszawa, 25.12.1970)”, in: Stefan Wyszyński, W sercu stolicy (Warszawa: Soli Deo, PAX, 2000), 156; Stefan Wyszyński, "Problem pracy górników w Polsce. List do księdza biskupa Herberta Bednorza (2.02.1978)", in: Stefan Wyszyński, Nauczanie społeczne 1946-1981 (Warszawa: ODISS, 1990), 810.

58 Wyszyński, Miłość i sprawiedliwość społeczna, 149.

59 Janusz Mariański, "Demokracja bez wartości? Refleksje wokół encykliki «Centesimus annus» i sytuacji w Polsce”, in: Wartości u podstaw demokracji, red. Janusz Nagórny, Andrzej Derdziuk (Lublin-Sandomierz: Wydawnictwo Diecezjalne, 2002), 39. 
In other words, democracy and the concept of a democratic state of law inscribed in its ministerial character set a common direction for the Church and the state: respect for the dignity of the human person, a saturation of politics with morality, and influence on the axiological foundations of the legal order ${ }^{60}$. Thus, the quintessence of the concept of a democratic state of the law is best captured by looking at it through the prism of Christian anthropological assumptions. Only the implementation of the Catholic social teaching's guidelines and the Christian system of values can make a person "more human", and democracy not resemble a "house built on sand".

\section{Summary}

Undoubtedly, the teachings of the Primate - rooted in the conciliar tradition - place a strong emphasis on the good of all citizens over whom the authority is to watch over. In this way, citizens are also guaranteed their rights when fulfilling their obligations. The authorities perceived in this way are obliged to strive for the good of their subordinates and to facilitate the functioning of institutions that serve citizens. In other words, the state, in the sense of the Catholic social teaching of the Church, has meaning as long as it fulfills the right service towards the nation. In such an approach, the state is no longer just an end in itself, but a help and a means of achieving the good of the person and common goods of the communities that constitute society. At the same time, the idea of the rule of law is understood as the natural environment for development has far-reaching consequences in terms of extracting the essential elements of the common good of all citizens ${ }^{61}$.

In this sense, the teaching of Cardinal Wyszyński was not an attempt to create - a kind of - optimal socio-political system, nor an effort to reduce the doctrine of the Church to the role of Christian ideology. The voice of the Primate expressed undoubted concern for the specific social and political reality of the "Polish People's Republic", and his message, inscribed in the sphere of evangelical principles, was aimed at directing the involvement of Christians in the construction of "new heaven and a new earth" (2 P 3:13, Rev 21:1).

In the context of the above analyzes, however, the question of explaining a specific phenomenon arises: why did society accept the new system of socialist enslavement for so long and quite commonly and support it, despite arrests, repressions, censorship, lies and the use of violence?

In answering this question, it must be stated that the new ideology of the socialist state was a promise to build a non-capitalist industrial society while maintaining some features of a traditional community. At the price of political and economic freedom, the party authorities guaranteed social security and civilization and national advancement

60 Leo XIII, “Graves de communi” (1901), access 27.08.2020, http://www.vatican.va/content/leo-xiii/en/encyclicals/ documents/hf_l-xiii_enc_18011901_graves-de-communi-re.html.

61 Stefan Wyszyński, “«Homo Politicus». III kazanie świętokrzyskie (27.01.1974)”, in: Stefan Wyszyński, Nauczanie społeczne 1946-1981 (Warszawa: ODISS, 1990), 591. 
to representatives of the lower classes, which primarily concerned the inhabitants of the countryside. Besides, there was a natural and enthusiastic reconstruction of the country from the war damage, often used for propaganda purposes. Notably, the Church at that time in Poland, despite its hostile environment, retained its autonomy and performed important social functions, becoming a guarantor of national continuity and identity.

Nevertheless, for most of the history of the Polish People's Republic, Poles accepted the ideological foundations of the communist regime, while rejecting the rules of functioning of the systemic institutions of the socialist state. This conditional acceptance was expressed by the slogan "socialism yes, distortions no", accompanying the social protests until August 1980. The decisive rejection of the system came only after the harrowing experiences of "Solidarity" and the brutal events of martial law.

\section{Bibliography}

Antoszewski, Andrzej, Teresa Łoś-Nowak. "Państwo". In: Leksykon politologii, eds. Andrzej Antoszewski, Ryszard Herbut, 260-273. Wrocław: Wydawnictwo Uniwersytetu Wrocławskiego, 1995.

Bartnik, Czesław Stanisław. Pedagogia narodowa prymasa Stefana Wyszyńskiego. Lublin: KUL, 2001.

Borowik, Zbigniew. "Wspólnota państwowa w nauczaniu Kardynała Stefana Wyszyńskiego”. Życie Katolickie 7-8 (1984): 142-150.

Brunner, Georg. "Legitimacy Doctrines and Legitimation Procedures in East European Systems". In: Political Legitimation in Communist States, eds. T.H. Rigby, Ferenc Feher, 27-44. London-New York: Palgrave Macmillan, 1982.

Clapham, Chistopher. "Clientelism and the state". In: Privatepatronage and public power, ed. Christopher Clapham, 4-16. London: Palgrave Macmillan, 1982.

Cochran, Clarke E. "The Thin Theory of Community: The Communitarians and their Critics". Political Studies 32 (1989): 422-435.

Cudworth, Erika. The Modern State: Theories and Ideologies. Edinburgh: Edinburgh University Press, 2007.

Cunningham, Frank. Democratic Theory and Socialism. Cambridge: Cambridge University Press, 1987.

Erman, Eva, Anders Uhlin. Legitimacy Beyond the State? Re-examining the Democratic Credentials of Transnational Actors. New York: Palgrave Macmillan, 2010.

Etzioni, Amitai. The Spirit of Community. New York: Crown Books, 1993.

Fabienne, Peter. "Legitimate Political Authority and Expertise". In: Legitimacy: The State and Beyond, eds. Wojciech Sadurski, Michael Sevel, Kevin Walton, 32-42. New York-London: Oxford University Press, 2019.

Ficek, Ryszard. Christians in Socio-Political Life: An Applied Analysis of the Theological Anthropology of Cardinal Stefan Wyszyński Primate of Poland. Toruń: Wydawnictwo Adam Marszałek, 2020. 
Ficek, Ryszard. Zaangażowanie chrześcijan w życie publiczne w kontekście nauczania kardynała Stefana Wyszyńskiego prymasa Polski. Lublin: Gaudium, 2020.

Friedman, Milton. Capitalism and Freedom. Chicago: University of Chicago Press, 1962.

John Paul II. “Centessimus annus”. Access 27.08.2020. http://www.vatican.va/content/johnpaul-ii/en/encyclicals/documents/hf_jp-ii_enc_01051991_centesimus-annus.html.

John Paul II. "Reconciliatio et paenitentia”. Access 27.08.2020. https://w2.vatican.va/content/ john-paul-ii/en/apost_exhortations/documents/hf_jp-ii_exh_02121984_reconciliatio-et-paenitentia.html.

John Paul II. "Sollicitudo rei socialis". Access 27.08.2020. http://www.vatican.va/content/ john-paul-ii/en/encyclicals/documents/hf_jp-ii_enc_30121987_sollicitudo-rei-socialis. html.

John XXIII. "Mater et Magistra". Access 27.08.2020. http://www.vatican.va/content/john-XXiii/en/encyclicals/documents/hf_j-xxiii_enc_15051961_mater.html.

Kowalczyk, Stanisław. U podstaw demokracji: Zagadnienia aksjologiczne. Lublin: RW KUL, 2001.

Kowalska, Joanna. "Kardynał Wyszyński w walce o człowieka sumienia”. Społeczeństwo 26, 3 (2016): 131-136.

Lauterpacht, Hersch. Recognition in International Law. New York: Cambridge University Press, 2012.

Leo XIII. "Diuturnum” (29.06.1881). Access 27.08.2020. http://www.vatican.va/content/leoxiii/en/encyclicals/documents/hf_1-xiii_enc_29061881_diuturnum.html.

Leo XIII. “Graves de communion” (1901). Access 27.08.2020. http://www.vatican.va/content/ leo-xiii/en/encyclicals/documents/hf_1-xiii_enc_18011901_graves-de-communi-re.html.

Leo XIII. "Libertas" (20.06.1892). Access 27.08.2020. http://c.vatican.va/content/leo-xiii/en/ encyclicals/documents/hf_1-xiii_enc_20061888_libertas.html.

Lewis, Paul. Eastern Europe: Political Crisis and Legitimation. London-Sydney: Croom Helm, 1984.

Mann, Michael. "The Ideology of Intellectuals and Other People in the Development of Capitalism". In: Stress and Contradiction and Modern Capitalism, eds. Leon Lindberg and Robert Alford, 268-287. Lexington, MA: Lexington Books, 1975.

Mariański, Janusz. "Demokracja bez wartości? Refleksje wokół encykliki «Centesimus annus» i sytuacji w Polsce". In: Wartości u podstaw demokracji, red. Janusz Nagórny, Andrzej Derdziuk, 29-71. Lublin-Sandomierz: Wydawnictwo Diecezjalne, 2002.

Maritain, Jacques. "Chrześcijaństwo i demokracja”. Znak 4 (1992): 45-47.

Mayntz, Renate. "Legitimacy and the Directive Capacity of the Political System". In: Stress and Contradiction in Modern Capitalism: Public Policy and the Theory of the State, ed. Leon N. Lindberg, 272-283. Lexington: Mass, Lexington Books, 1975.

Nelson, Brian. The Making of the Modern State: a Theoretical Evolution. New York: Palgrave Macmillan, 2006.

Pakulski, Jan. "Legitimacy and Mass Compliance: Reflection on Max Weber and Soviet-type Societies". British Journal of Political Science 16 (1986): 451-472. 
Paul VI. "Populorum progression”. Access 27.08.2020. http://www.vatican.va/content/paul-vi/ en/encyclicals/documents/hf_p-vi_enc_26031967_populorum.html.

Pius XII. “Orędzie radiowe wygłoszone w wigilię Bożego Narodzenia 1944 r.”. Acta Apostolicae Sedis 37 (1945): 5-23, 36.

Przeworski, Adam. Capitalism and Social Democracy. Cambridge: Cambridge University Press, 1985.

Rawls, John. A Theory of Justice. Cambridge: Harvard University Press, 1971.

Rybicki, Zygmunt, Andrzej Werblan. "Historyczne miejsce demokracji socjalistycznej". Państwo i Prawo 8-9 (1977): 23-38.

Sartori, Giovanni. The Theory of Democracy Revisited. Chatham: Chatham N.J., 1987.

Skorowski, Henryk. Problematyka praw człowieka: Stadium z nauki społecznej Kościoła. Warszawa: Wydawnictwa Akademii Teologii Katolickiej, 1996.

Sokół, Wojciech. Legitymizacja systemów politycznych. Wydawnictwo UMCS, Lublin 1997.

Sternberger, Reiner. "Legitimacy". In: International Encyclopedia of Social Science. Vol. IX, ed. David E. Sills, 244-246. New York: Macmillan, 1989.

Sutor, Berhard. Etyka polityczna: Ujęcie całościowe na gruncie chrześcijańskiej nauki społecznej, 42-43. Warszawa: Kontrast, 1994.

Weber, Max. Economy and Society. Los Angeles-London: Berkeley, 1978.

Wyszyński, Stefan. “"Abyście byli synami światłości». Do naukowców Warszawy (21.03.1959)”. In: Stefan Wyszyński, Nauczanie społeczne 1946-1981, 123-128. Warszawa: ODISS, 1990.

Wyszyński, Stefan. “Apel Prymasa Polski ze stolicy. Do wszystkich dzieci Wspólnej Ojczyzny (Warszawa, 25.12.1970)”. In: Stefan Wyszyński, W sercu stolicy, 153-159, Warszawa: Soli Deo, PAX, 2000.

Wyszyński, Stefan. "Bez ofiar i wyrzeczeń nie ma zwycięstwa. Warszawa - kościół Matki Bożej Zwycięskiej 16 VIII 1970”. In: Stefan Wyszyński, Z gniazda orląt, 101-109. Rome: Papieski Instytut Studiów Kościelnych, 1972.

Wyszyński, Stefan. "Głos synodu na temat sprawiedliwości w świecie. Po powrocie z Synodu Biskupów. Warszawa 6.01.1972”. In: Stefan Wyszyński, Nauczanie społeczne 1946-1981, 477-482. Warszawa: ODISS, 1990.

Wyszyński, Stefan. “«Homo Dei». I Kazanie Świętokrzyskie 13.01.1974”. In: Stefan Wyszyński, Nauczanie społeczne 1946-1981, 574-580. Warszawa: ODISS, 1990.

Wyszyński, Stefan. “«Homo Politicus». III kazanie świętokrzyskie (27.01.1974)”. In: Stefan Wyszyński, Nauczanie społeczne 1946-1981, 589-596. Warszawa: ODISS, 1990.

Wyszyński, Stefan. "Jakiej chcecie Polski? Do młodzieży akademickiej w Warszawie 22.03.1972”. In: Stefan Wyszyński, Nauczanie społeczne 1946-1981, 488-493. Warszawa: ODISS, 1990.

Wyszyński, Stefan. "Kamienie węgielne budowania na górach świętych. Na Jasnej Górze po powrocie z uwięzienia 2.11.1956”. In: Stefan Wyszyński, Nauczanie społeczne 1946-1981, 62-66. Warszawa: ODISS, 1990. 
Wyszyński, Stefan. "Kościół jest najbliższym sprzymierzeńcem waszych dążeń. GnieznoDom Prymasowski 4.02.1981”. In: Stefan Wyszyński, Do „Solidarności”, Rady i wskazania, 47-56. Warszawa: Oficyna Naukowa, 1996.

Wyszyński, Stefan. Miłość i sprawiedliwość społeczna. Poznań: Pallottinum, 1993.

Wyszyński, Stefan. "Naród - Kościół - Państwo. Kazanie świętokrzyskie (25.01.1976)". In: Stefan Wyszyński, Nauczanie społeczne 1946-1981, 705-713. Warszawa: ODISS, 1990.

Wyszyński, Stefan. “«Nauczycielu prawdomówny!». Do nauczycieli Warszawy 6.11.1960”. In: Stefan Wyszyński, Nauczanie społeczne 1946-1981, 168-173. Warszawa: ODISS, 1990.

Wyszyński, Stefan. "O chrześcijańskim wyzwoleniu człowieka, List pasterski na adwent 1946”. In: Stefan Wyszyński, Nauczanie społeczne 1946-1981, 14-28. Warszawa: ODISS, 1990.

Wyszyński, Stefan. “O katolickiej woli życia. List pasterski na Wielkanoc 1947”. In: Stefan Wyszyński, Nauczanie społeczne 1946-1981, 29-40. Warszawa: ODISS, 1990.

Wyszyński, Stefan. "O moralną odnowę narodu. Po ogłoszeniu encykliki «Pacem in terris». Białystok 2.06.1963”. In: Stefan Wyszyński, Nauczanie społeczne 1946-1981, 1005-1011. Warszawa: ODISS, 1990.

Wyszyński, Stefan. "O pokoju na ziemi. Po ogłoszeniu encykliki «Pacem in terris». Białystok 2.06.1963”. In: Stefan Wyszyński, Nauczanie społeczne 1946-1981, 212-215. Warszawa: ODISS, 1990.

Wyszyński, Stefan. “Odpowiedzialność - obowiązki i prawa w życiu narodu. Jasna Góra 26.08.1980”. In: Stefan Wyszyński, Nauczanie społeczne 1946-1981, 948-954. Warszawa: ODISS, 1990.

Wyszyński, Stefan. "Pokój jest dziełem sprawiedliwości. Na Boże Narodzenie 25.12.1972". In: Stefan Wyszyński, Nauczanie społeczne 1946-1981, 524-528. Warszawa: ODISS, 1990.

Wyszyński, Stefan. "Prawa osoby ludzkiej w społeczeństwie. Warszawa - kościół św. Anny 18.03.1957". In: Stefan Wyszyński, Kazania i przemówienia autoryzowane 1956-1981. Vol. 1-67. Archiwum Instytutu Prymasowskiego w Warszawie. Vol. II, 4-5.

Wyszyński Stefan. "Problem pracy górników w Polsce. List do księdza biskupa Herberta Bednorza (2.02.1978)". In: Stefan Wyszyński, Nauczanie społeczne 1946-1981, 810-814. Warszawa: ODISS, 1990.

Wyszyński, Stefan. "Prymat osoby nad rzeczą. Z okazji 30. rocznicy powstania Wydziału Filozofii Chrześcijańskiej KUL 7.3.1976”. In: Stefan Wyszyński, Nauczanie społeczne 1946-1981, 714-718. Warszawa: ODISS, 1990.

Wyszyński, Stefan. “«Res sacra homo». Podczas jubileuszu świętego Wincentego à Paulo w Krakowie 27.09.1960”. In: Stefan Wyszyński, Nauczanie społeczne 1946-1981, 150-156. Warszawa: ODISS, 1990.

Wyszyński, Stefan. "Stawiamy na rodzinę. Do referentek poradnictwa rodzinnego w parafiach. Gniezno 6.02.1973”. In: Stefan Wyszyński, Prymat człowieka w ładzie społecznym, 55-65. Londyn: Odnowa, 1976.

Wyszyński, Stefan. "Sumienie prawe u podstaw odnowy życia narodowego. Do wiernych (Warszawa, 6.01.1981)”. In: Stefan Wyszyński, Nauczanie społeczne 1946-1981, 986-994. Warszawa: ODISS, 1990. 
Wyszyński, Stefan. “«Sursum corda». Z kazania do górali tatrzańskich. Zakopane 1957”. In: Stefan Wyszyński, Wszystko postawitem na Maryję, 142-148. Paris: Editions du Dialogue, 1980.

Wyszyński, Stefan. “«W obronie życia Polaków», Warszawa-Leszno 9.03.1975”. In: Stefan Wyszyński, Prymat człowieka w ładzie społecznym, 184-188. London: Odnowa, 1976.

Wyszyński, Stefan. "Wołanie ludzkości o obecność Kościoła w świecie współczesnym. Warszawa 18.04.1973”. In: Stefan Wyszyński, “Idzie nowych ludzi plemię...”. Wybór przemówień i rozważań, 91-98. Poznań-Warszawa: Pallottinum, 1973.

Wyszyński, Stefan. “Zmaganie się sprawiedliwości i miłości. Zwycięstwo miłości. Warszawakościół oo. Bazylianów 6.04.1968”. In: Stefan Wyszyński, “Idzie nowych ludzi plemię...”. Wybór przemówień i rozważań, 232-237. Poznań-Warszawa: Pallottinum, 1973. 